\title{
WELCOMING ADDRESS
}

\author{
by
}

\author{
Gudmundur Magnusson
}

(Rector of the University of Iceland, Háskóla Islands, via Sudurgötu, 101 Reykjavik, Iceland)

Madam President of Iceland, Professor Röthlisberger, Ladies and Gentlemen:

Welcome to the top of the world, to Iceland, and the University of Iceland.

We know that the name of the country is a deterrent to many people, but obviously an attraction for glaciologists and James Bond.

And the country is also the middle of the world, if you believe in the continental drift theory. The Eurasian and the American plates meet here and there is a fault in the ground near Thingvellir, which is widening by some millimetres, on the average, per year. You can stand astride this crevice and decide whether you want to drift towards the East or the West.

It is an ill wind that blows nobody good and this very geological fact explains the valuable geothermal resources of Iceland.

As we all know, the glaciers and glacial rivers are a valuable economic resource in Iceland. At the same time, they affect the everyday life of the people in many ways, for example with regard to climatic conditions and communications.

We are very proud that our University has taken an active part in research on the mass balance of the glaciers and the water resources of the country. The results are of direct relevance for the water power companies and the people in general. It has been established, for example, that the water we are drinking now, here in Reykjavik, is the rain that fell on Hrafna-Flóki in the time of the first settlers.

Our late professor, Sigurdur Thórarinsson, was a pioneer in glacial research and an Honorary Member of your distinguished society.

Iceland is therefore a logical place to host a symposium on glacier mapping and surveying. Iceland is hosting this symposium on behalf of the Nordic countries. The Nordic Cultural Fund has made a financial contribution to the symposium, at the recommendation of the Nordic Research Council. As a member of that council, I welcome this opportunity to tell you that it puts great emphasis on research in Arctic areas and it stresses the inte-naticnal character of science.

I thank all those who have made this symposium possible and wish you success in your sessions. I also hope you will get an opportunity to become acquainted with our culture and to travel in our country. 